\title{
Effects of antirheumatoid drugs on the production and action of porcine catabolin
}

\author{
H. SHEPPEARD, L. M. C. PILSWORTH, B. HAZLEMAN, ${ }^{*}$ AND J. T. DINGLE \\ From the Strangeways Research Laboratory, Worts Causeway, Cambridge CB1 4RN, and *Addenbrooke's \\ Hospital, Hills Road, Cambridge
}

SUMMARY We report the effects of some common antirheumatic drugs on the production of catabolin from synovium and on its action on cartilage. A method is described to generate reproducible amounts of catabolin from synovial mince. Aspirin, Clozic (ICI 55 897), and gold were without effect on the catabolin system. Penicillamine at high doses enhanced the action of catabolin, while chloroquine inhibited catabolin's effect on cartilage. Prednisolone inhibited the production of catabolin without affecting its action. This inhibition was produced by very low doses of prednisolone $(25 \mathrm{ng} / \mathrm{ml})$ and was dose-dependent.

Synovial tissue in culture produces a factor, catabolin, which causes living cartilage in vitro to resorb its matrix. ${ }^{1-4}$ It is assayed by its ability to cause loss of glycosaminoglycan from cartilage in culture. Medium conditioned by pig synovium contains only one major component active in inducing matrix loss in bovine nasal cartilage, a protein of molecular weight $17000-18000$ and an isoelectric point of $\mathrm{pH} 4 \cdot 6 .{ }^{5}$.

The experiments shown below were undertaken to investigate the effects of some common antirheumatoid drugs on the production of catabolin from synovium and on its action on cartilage in culture. It was necessary to develop a means of generating reproducible quantities of catabolin from synovial mince so that the amount of catabolin produced from tissue treated with the various drugs could confidently be compared with that from the control cultures.

\section{Materials and methods}

PRODUCTION OF CATABOLIN

The joint capsule was dissected from the third and fourth metacarpophalangeal joints of freshly killed young pigs and the synovium carefully removed. Pooled synovial tissue was minced, washed, and centrifuged at $600 \mathrm{~g}$ for 10 minutes to produce a compact mass of tissue, which was aliquoted by filling a sterile plastic mould. The measured volume of mince was spread thinly on to filter paper supported by a stainless steel grid and cultured in $2 \mathrm{ml}$ of Dulbecco's modified Eagle's medium supplemented with $60 \mu \mathrm{g}$

Accepted for publication 3 September 1981.

Correspondence to Dr L. M. C. Pilsworth. per $\mathrm{ml}$ glutamine, penicillin/streptomycin (200 IU per $\mathrm{ml}$ and $200 \mu \mathrm{g}$ per $\mathrm{ml}$ respectively), and $5 \%$ fetal calf serum. The cultures were incubated at $37^{\circ} \mathrm{C}$ in an atmosphere of $5 \% \mathrm{CO}_{2}, 20 \% \mathrm{O}_{2}$, and $75 \% \mathrm{~N}_{2}$ for 6 days, the medium being changed at day 3 . Samples of mince which were killed by freezing and thawing were cultured to serve as controls. Medium harvested at day 3 and day 6 from each synovial mince was pooled and diluted with $5 \mathrm{ml}$ of culture medium to yield $9 \mathrm{ml}$ for assay of catabolin activity.

The following drugs were added to the cultures of synovial mince: aspirin, Clozic (ICI 55 897), gold (sodium aurothiomalate), prednisolone, D-penicillamine, and chloroquine. The drugs were added at various concentrations, including those reported to be found in the plasma and tissues of patients undergoing drug therapy (Table 1 ). Between 3 and 6 cultures of synovial mince were used in each experimental group.

\section{A S S A O O CATABOLIN}

Culture media conditioned by the synovial mince were added to discs of cartilage prepared from bovine nasal septum, which were then maintained for 8 days. ${ }^{3}$ Discs which had been killed by freezing and thawing were included in each experiment. At the end of the culture period the discs were digested with papain, and the glycosaminoglycan present in the digests and the medium was measured spectrophotometrically with dimethylmethylene blue. ${ }^{5}$ Catabolin activity was expressed as:

$$
\frac{\text { chondroitin sulphate released into medium }}{\text { total chondroitin sulphate from each disc }} \times 100 \text {. }
$$


Table 1 The concentrations of antirheumatoid drugs used in the experiments and their relationship to therapeutic levels

\begin{tabular}{|c|c|c|c|}
\hline Drug & $\begin{array}{l}\text { Concentration } \\
\text { used }\end{array}$ & Pharmacological Rationale & References \\
\hline Aspirin & $250 \mu \mathrm{g} / \mathrm{ml}$ & $\begin{array}{l}\text { Plasma therapeutic range } \\
200-300 \mu \mathrm{g} / \mathrm{ml}\end{array}$ & Bayles $^{6}$ \\
\hline Clozic (ICI 55 897) & $140 \mu \mathrm{g} / \mathrm{ml}$ & $\begin{array}{l}\text { Plasma therapeutic range } \\
100-300 \mu g / \mathrm{ml}\end{array}$ & $\begin{array}{l}\text { Billingham } \\
\text { personal communication }\end{array}$ \\
\hline $\begin{array}{l}\text { Gold } \\
\text { (Myocrisin) }\end{array}$ & $\begin{array}{r}10 \mu \mathrm{g} / \mathrm{ml} \\
100 \mu \mathrm{g} / \mathrm{ml}\end{array}$ & $\begin{array}{l}\text { Peak plasma level } \\
\text { Tissue level }\end{array}$ & $\begin{array}{l}\text { Jessop and Johns } \\
\text { Grahame et al. }\end{array}$ \\
\hline $\begin{array}{l}\text { Prednisolone } \\
\text { (Codesol) }\end{array}$ & $\begin{array}{c}2.5 \mathrm{ng} / \mathrm{ml} \\
25 \mathrm{ng} / \mathrm{ml} \\
250 \mathrm{ng} / \mathrm{ml} \\
2.5 \mu \mathrm{g} / \mathrm{ml}\end{array}$ & $\begin{array}{l}10^{-1} \times \text { peak plasma level } \\
\text { Equivalent to physiological } \\
\text { cortisol level } \\
\text { Peak plasma following } \\
10 \text { mg dose } \\
10 \times \text { peak plasma level }\end{array}$ & Pickup ${ }^{9}$ \\
\hline $\begin{array}{l}\text { D-penicillamine } \\
\text { (Distamine) }\end{array}$ & $\begin{array}{l}50 \mu \mathrm{g} / \mathrm{ml} \\
100 \mu \mathrm{g} / \mathrm{ml} \\
250 \mu \mathrm{g} / \mathrm{ml} \\
500 \mu \mathrm{g} / \mathrm{ml}\end{array}$ & $\begin{array}{l}\text { Peak plasma level following } \\
1 \mathrm{~g} \text { dose } \\
\text { Plasma concentrations on } \\
1 \mathrm{~g} \text { daily } \\
5 \times \text { peak plasma level } \\
10 \times \text { peak plasma level }\end{array}$ & $\begin{array}{l}\text { Gibbs and Walshe } \\
\text { Mowat }^{10}\end{array}$ \\
\hline $\begin{array}{l}\text { Chloroquine } \\
\text { phosphate } \\
\text { (Avloclor) }\end{array}$ & $\begin{array}{r}200 \mathrm{ng} / \mathrm{ml} \\
400 \mathrm{ng} / \mathrm{ml} \\
4 \mu \mathrm{g} / \mathrm{ml} \\
40 \mu \mathrm{g} / \mathrm{ml}\end{array}$ & $\begin{array}{l}\text { Peak plasma level following } \\
500 \text { mg dose } \\
10^{-2} \times \text { tissue level } \\
10^{-1} \times \text { tissue level } \\
\text { Tissue level }(200 \times \text { peak } \\
\text { plasma level })\end{array}$ & Goodman and Gilman ${ }^{12}$ \\
\hline
\end{tabular}

SI conversion: $\mu \mathrm{g} / \mathrm{ml}=\mathrm{mg} / \mathrm{l} ; \mathrm{ng} / \mathrm{ml} \times 10^{3}=\mathrm{mg} /$.

As the drugs added to the synovial mince were still present during the bioassay with the bovine nasal cartilage, their direct effects on the action of catabolin on cartilage were assessed as follows. Partially purified catabolin ${ }^{3}$ was added to cultures of bovine nasal cartilage discs in the presence of prednisolone, D-penicillamine, or chloroquine. The action of D-penicillamine alone on cartilage was examined by adding the drug to cultures of both living and killed discs.

Chondroitin sulphate release was measured as described above.

EFFECT OF CHLOROQUINE ON UPTAKE OF
${ }^{3}$ H-GLYCINE BYBOVINE NASAL CARTILAGE The effect of chloroquine on protein synthesis by the cartilage was studied. Groups of discs (3 per group) were cultured for 8 days as before in the presence of chloroquine at concentrations of $4 \mu \mathrm{g} / \mathrm{ml}, 40 \mu \mathrm{g} / \mathrm{ml}$ and $400 \mu \mathrm{g} / \mathrm{ml}$ (SI conversion: $\mu \mathrm{g} / \mathrm{ml}=\mathrm{mg} / \mathrm{l}$ ). At day 1 of culture some of the discs were incubated for 4 hours in culture medium containing $5 \mu \mathrm{Ci}$ per $\mathrm{ml}$ ${ }^{3} \mathrm{H}$-glycine (Amersham, Bucks) and washed 3 times in medium containing $1 \mathrm{mg} / \mathrm{ml}$ non-radioactive glycine. At the end of the culture period the discs were left overnight in a mixture of ethanol and 1 $\mathrm{mg} / \mathrm{ml}$ glycine, washed again 3 times in ethanolglycine and digested with papain as described. Sam- ples of this digest were taken for liquid scintillation counting in a mixture of toluene scintillator and picoflour 30 (Packard) 50:50 v/v.

The procedure was repeated on day 4 , day 6 , and day 8 .

\section{Results}

Medium from the cultures of synovial mince caused marked release of chondroitin sulphate from discs of bovine nasal cartilage.

By using a mould to measure out synovial mince for culture we obtained reproducible wet weights of tissue aseptically (58.2 $\mathrm{mg}$ wet weight, SEM $1.5 \%$, $n=8)$. The variation in release of chondroitin sulphate produced by medium from the synovial cultures was considered to show acceptable reproducibility for this type of bioassay (52\%, SEM $3 \%, n=8)$ in 8 days. Dead cartilage cultured under the same conditions produced $22 \cdot 1 \%($ SEM $1 \%, n=8)$ release of chondroitin sulphate, and control cultures of living cartilage in medium alone resulted in $19.4 \%$ (SEM $1 \cdot 1 \%, n=8$ ) release in 8 days. There was no significant difference between chondroitin sulphate release from bovine nasal cartilage cultured in the presence of medium from control synovial mince and that from synovial mince treated with either aspirin, Clozic, or gold (Fig. 1) at various doses. 


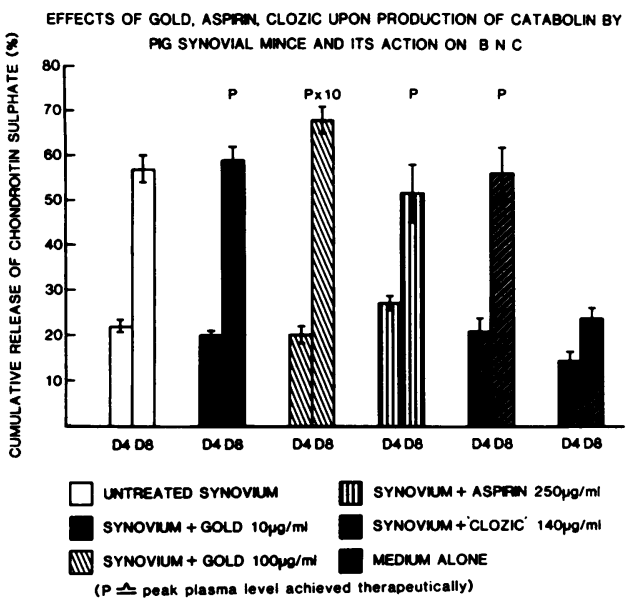

Fig. 1 Cumulative release of chondroitin sulphate from bovine nasal cartilage cultured for 4 and 8 days in the presence of spent medium from cultures of untreated pig synovial mince, and of medium from mince cultured for 6 days in the presence of gold, aspirin, and Clozic.

The addition of prednisolone to cultures of synovial mince caused medium from these cultures to elicit less breakdown of bovine nasal cartilage than was produced by spent medium from untreated synovium. This effect was dose-dependent, a highly significant $(p=\ll 0.001)$ decrease in chondroitin sulphate release being produced by medium from synovial cultures which had been maintained in the presence of $25 \mathrm{ng} / \mathrm{ml}$ prednisolone (Fig. 2).

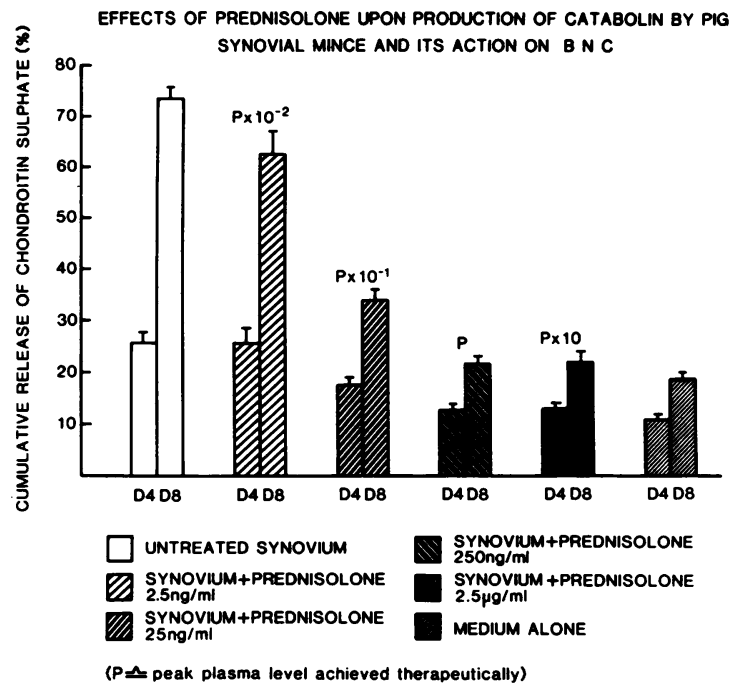

Fig. 2 Cumulative release of chondroitin sulphate from discs of bovine nasal cartilage cultured for 4 days or 8 days in the presence of medium from cultures of untreated pig synovium, and of medium from mince maintained in the presence of increasing doses of prednisolone.

When prednisolone $(250 \mathrm{ng} / \mathrm{ml})$ was added to cultures of bovine nasal cartilage in the presence of partially purified catabolin no inhibition of degradation was produced (Fig. 3).

Medium from cultures of synovial mince maintained in the presence of $500 \mu \mathrm{g} / \mathrm{ml}$ D-penicillamine

\section{EFFECT OF PREDNISOLONE UPON THE ACTION OF PARTIALLY PURIFIED CATABOLIN ON BNC}

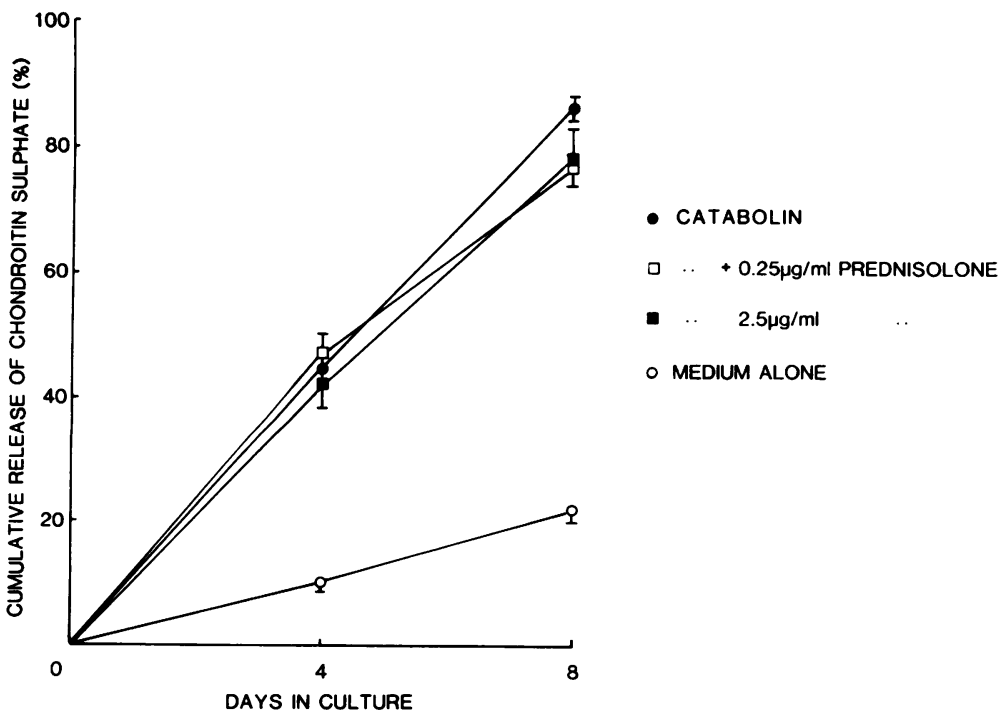

Fig. 3 The addition of prednisolone has no significant effect upon the release of chondroitin sulphate by cartilage discs cultured in the presence of partially purified catabolin. 


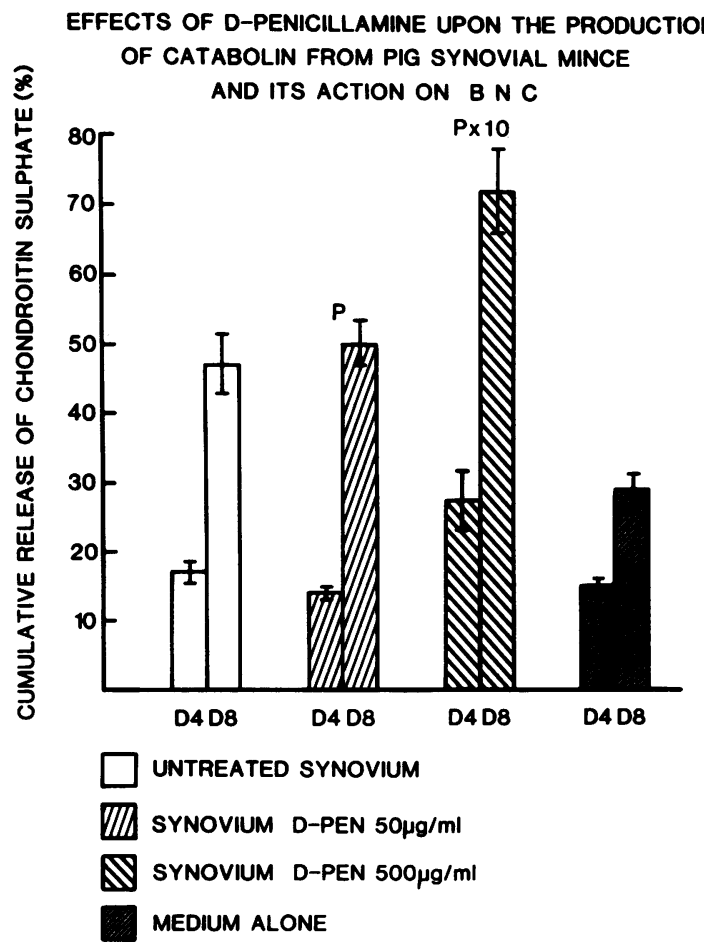

( $P \bumpeq$ ^صeak plasma level achieved therapeutically)

Fig. 4 Cumulative release of chondroitin sulphate from discs of bovine nasal cartilage cultured for 4 days and 8 days in the presence of medium from untreated pig synovium, and of medium from mince maintained in the presence of increasing doses of D-penicillamine.

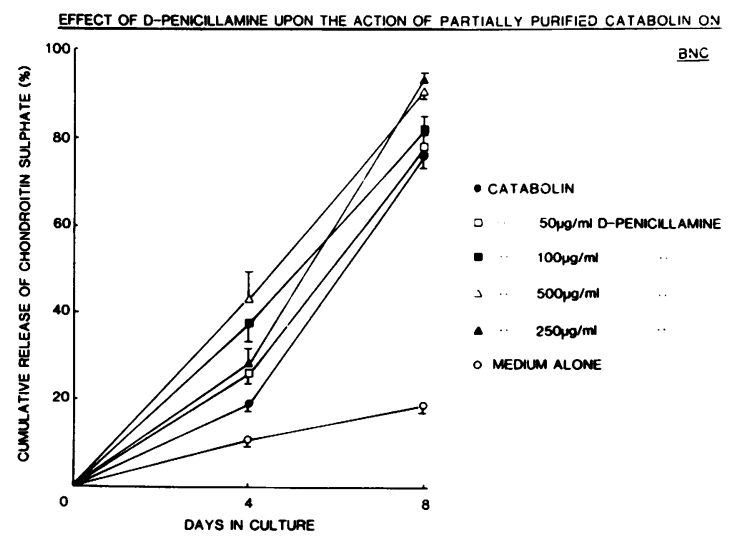

Fig. 5 The cumulative release of chondroitin sulphate from discs of bovine nasal cartilage maintained in vitro in the presence of partially purified catabolin is enhanced by the addition of D-penicillamine.
EFFECTS OF CHLOROQUINE UPON THE PRODUCTION OF CATABOLIN BY PIG SYNOVIAL MINCE AND ITS ACTION ON B N C

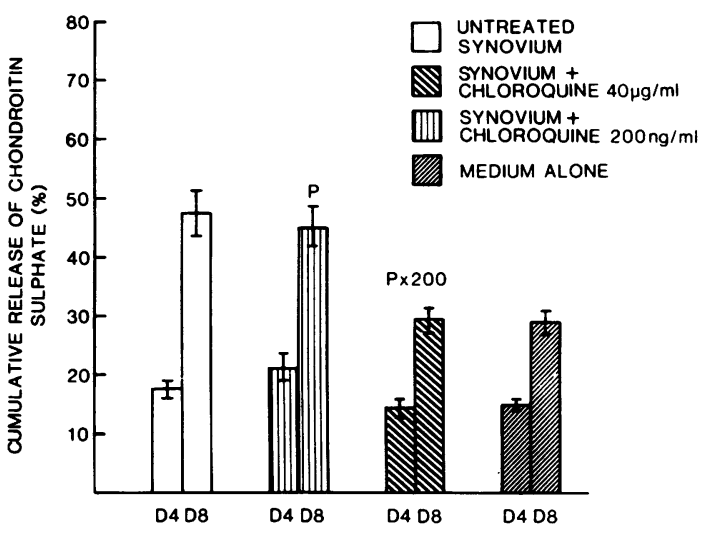

( $P \bumpeq$ $\bumpeq$ peak plasma level achieved therapeutically)

Fig. 6 Cumulative release of chondroitin sulphate from discs of bovine nasal cartilage cultured for 4 days or 8 days in the presence of medium from untreated pig synovium, and of medium from mince maintained in the presence of chloroquine.

caused more breakdown of the cartilage discs than did the spent medium from untreated mince. The addition of $50 \mu \mathrm{g} / \mathrm{ml} \mathrm{D}$-penicillamine to the synovial cultures had no effect (Fig. 4). When this drug was added to cartilage cultures in addition to partially purified catabolin, enhancement of the catabolin-induced chondroitin sulphate release occurred (Fig. 5) at doses of $250 \mu \mathrm{g} / \mathrm{ml}$ and $500 \mu \mathrm{g} / \mathrm{ml}$ D-penicillamine $(\mathrm{p}=\ll 0 \cdot 01)$.

D-penicillamine alone had no effect on breakdown of either living or dead cartilage.

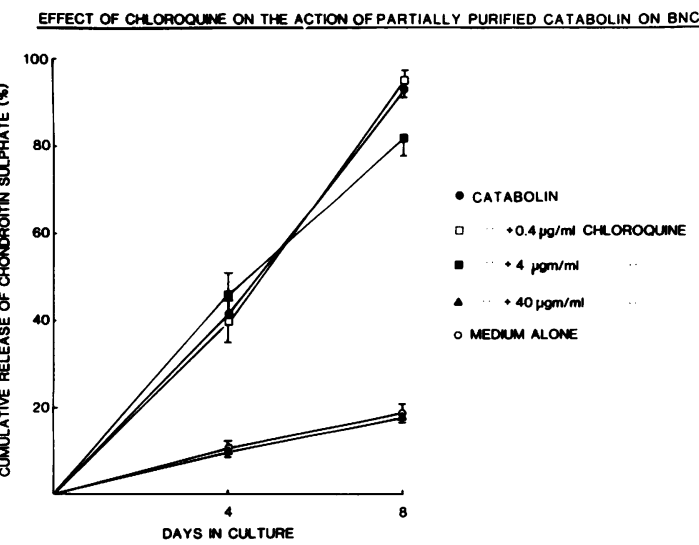

Fig. 7 The addition of chloroquine to cultures of bovine nasal cartilage discs reduces the release of chondroitin sulphate produced by partially purified catabolin. 


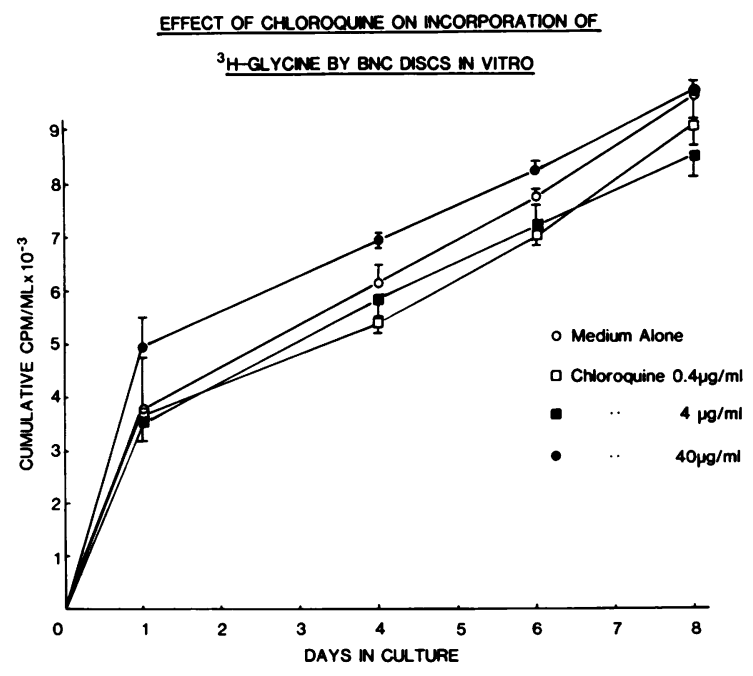

Fig. 8 Uptake of ${ }^{3} \mathrm{H}$-glycine by cartilage discs in in vitro is unimpaired by the addition of chloroquine $(0.4-40 \mu \mathrm{g} / \mathrm{ml})$ to the culture medium.

After the addition of chloroquine to cultures of synovial mince, the resulting medium caused less breakdown of cartilage than did spent medium from untreated mince (Fig. 6). This effect was significant $(\mathrm{p}=<0 \cdot 01)$ at dose levels of $40 \mu \mathrm{g} / \mathrm{ml}$ chloroquine. The addition of chloroquine to the cartilage culture in the presence of partially purified catabolin also produced inhibition of catabolin-induced breakdown, the inhibition being dose-dependent (Fig. 7), a significant inhibition was produced by a dose of 40 $\mu \mathrm{g} / \mathrm{ml}(\mathrm{p}=0 \cdot 01-0 \cdot 05)$.

Incorporation of ${ }^{3} \mathrm{H}$-glycine by the cartilage discs in culture was unimpaired by chloroquine at doses of $400 \mathrm{ng} / \mathrm{ml}$ (Fig. 8).

\section{Discussion}

It proved possible to standardise the culture conditions for catabolin production from synovial mince, so that the resulting release of glycosaminoglycan from the discs of nasal cartilage used in the assay was in close agreement, permitting the analysis of experimental modification of catabolin production.

Aspirin, Clozic, and gold were without effect on either the production of catabolin or its action on cartilage. Clozic has now been withdrawn by ICI and will not become available on prescription.

Prednisolone inhibited production of catabolin but did not interfere with its action on cartilage. This inhibition occurred at a concentration of $25 \mathrm{ng} / \mathrm{ml}$ prednisolone, a level well below those achieved when the drug is used for its anti-inflammatory or immunosuppressive effects. ${ }^{13}$ Other corticosteroids when added to human synovium in culture have been shown to exert a similar inhibition of cartilage resorption. ${ }^{14}$ Obviously caution must be exercised in extrapolating from organ culture experiments with animal tissues to chemotherapy of the human disease, but it is quite possible that catabolin production is suppressed in patients undergoing prednisolone therapy.

It is not known to what extent, if any, catabolin is stored by tissues, but any such residual catabolin would not be inhibited in its action on cartilage by prednisolone. The activity of catabolin on cartilage was not suppressed even by very high doses of the drug, levels at which the release of lysosomal enzymes from the cartilage itself would be substantially inhibited. ${ }^{13}$ The mechanism of cartilage resorption remains obscure.

Penicillamine when used at high dose levels, enhanced the action of catabolin. Although the drug has an extremely long biological half-life and has been reported to be concentrated in joint structures, ${ }^{1516}$ the levels effective in enhancing breakdown of cartilage in these experiments, namely, 250 $\mu \mathrm{g} / \mathrm{ml}$ and $500 \mu \mathrm{g} / \mathrm{ml}$, are unlikely to be achieved in clinical practice. ${ }^{1011}$ The drug alone had no effects on the cartilage discs but required the presence of catabolin to bring about matrix loss.

Chloroquine inhibited the action of catabolin on cartilage. Since it is catabolin's effect on cartilage which forms the basis for its assay, it is not possible to comment from these results about chloroquine's action on catabolin production. The dose levels required to produce the inhibition of activity were very high, but in animal studies, tissue concentrations of 200 to 700 times the plasma level of chloroquine have been measured. ${ }^{12}$ The concentrations effective in the experiments reported here could be reached in cells which accumulate the drug. ${ }^{17}$

Glycine incorporation by the cartilage discs cultured in the presence of chloroquine did not differ from that of the controls, implying that the drug is not toxic to chondrocytes.

This study is a first step in trying to understand whether the catabolin system can be modified by commonly used antirheumatic drugs. The increased cartilage destruction brought about by adding D-penicillamine is only of pharmacological interest as the effective doses are too high to be achieved clinically. Of the 2 drugs shown to cause a net sparing of cartilage, prednisolone caused a marked inhibition of the production of catabolin, while chloroquine exerted its effect by suppressing the action of catabolin. 


\section{References}

${ }^{1}$ Fell H B, Jubb R W. The effect of synovial tissue on the breakdown of articular cartilage in organ culture. Arthritis Rheum 1977; 20: 1359-71.

2 Dingle J T. Heberden Oration. Ann Rheum Dis 1979; 38: 201-14.

${ }^{3}$ Dingle J T, Saklatvala J, Hembry R, Tyler J, Fell H B, Jubb R. A cartilage catabolic factor from synovium. Biochem J 1979; 184: 177-80.

${ }^{4}$ Saklatvala J, Dingle J T. Identification of catabolin, a protein from synovium which induces degradation of cartilage in organ culture. Biochem Biophys Res Commun 1980; 96: 1225-31.

5 Saklatvala J. Characterization of catabolin: the major product of synovial tissue that induces resorption of cartilage proteoglycan in vitro. Biochem $J$ in press.

6 Bayles T B. Salicylate therapy for rheumatoid arthritis. In: Hollander J L, McCarty D J. eds. Arthritis and Allied Conditions. Philadelphia: Lea and Febiger, 1972: 448-54.

7 Jessop J D, Johns R G S. Serum gold determinations in patients with rheumatoid arthritis receiving sodium aurothiomalate. Ann Rheum Dis 1973; 32: 228-32.

${ }^{8}$ Grahame R, Billings R, Lawrence M, Marks V, Wood P J. Tissue gold levels after chrysotherapy. Ann Rheum Dis 1974; 33: 536-9.
${ }^{9}$ Pickup M E. Clinical pharmacokinetics of prednisone and prednisolone. Clin Pharmacokinet 1979; 4: 111-28.

${ }^{10}$ Gibbs K, Walshe J M. Studies with 35S-labelled DLpenicillamine in patients with Wilson's disease. $Q J$ Med 1971;40: 275-87.

${ }^{11}$ Mowat A G. Neutrophil chemotaxis in rheumatoid arthritis. Effect of D-penicillamine, gold salts, and levamisole. Ann Rheum Dis 1978; 37: 1-8.

12 Goodman L S, Gilman A. The Pharmacological Basis of Therapeutics. London. Bailliere and Tindall, 1975; 1050-3.

${ }^{13}$ Fauci A S. Glucocorticosteroid therapy: mechanisms of action and clinical considerations. Ann Intern Med 1976; 84: 304-15.

14 Steinberg J, Tsukamuto S, and Sledge C B. A tissue culture model of cartilage breakdown in rheumatoid arthritis. III The effects of antirheumatic drugs. Arthritis Rheum 1979; 22: 877-85.

15 Ruiz-Torres V A. Zur Pharmakokinetik und zum Stoffwechsel von D- und L-Penicillamin. 1. Mitteilung: Blutspiegel, Transport and Eiweisbindung. Arzneim Forsch 1974; 24: 914-7.

16 Ruiz-Torres V A. Zur Pharmakokinetik und zum Stoffwechsel von D- und L-Penicillamin. II Mitteilung: Verteilung von D- und L-Penicillamin ${ }^{14} \mathrm{C}$ M Organismus der Ratte nach peroraler verabfolgung. Arzneim Forsch 1974; 24: 1043-6.

${ }_{17}$ Weissmann G. The effects of steroids and other drugs on lysosomes. In: Dingle J T, Fell H B. eds. Lysosomes in Biology and Pathology. London: North Holland, 1969: 284-6. 